\title{
要旨
}

人工心肺（cardiopulmonary bypass：CPB）を使用した開心術では、血液温やへマトクリット值の変化に伴い、血 液粘度が $\mathrm{CPB}$ 開始時から終了時まで変動する。血液粘度は患者の循環動態に影響を及ぼすため、 $\mathrm{CPB}$ 中の有効なパ ラメータであると思われるが、一般的なモニタリング項目とはなっていない。本研究では、現在の CPBに扔いて使 用されている限外濾過回路を利用してリアルタイムに血液粘度を測定できるシステムを構築し、その性能を評価した。 本システムを使用してグリセリン水溶液、キサンタンガム水溶液、牛血の粘度を測定した結果は、回転粘度計の 測定結果とほぼ同一となり、誤差は土10\%以内であった。100〜 $500 \mathrm{~mL} / \mathrm{min}$ の流量では、血液濃縮器内の流れは層 流となるため、Hagen-Poiseuille の式を利用して流量と圧較差から粘度を算出することの有用性が示された。

血液粘度の変化は血管抵抗や CPB 回路の回路内圧にも影響を与える。本手法を用いることにより、リアルタイム に血液粘度を測定することが可能であり、粘度変化を定量的に認識することにより、患者末梢循環や CPB 回路の血 液粘度を考慮した適切な灌流状態の評価が可能になると考えられる。

索引用語：血液粘度、限外滤過回路、人工肺、圧力損失

\section{Development of real-time blood viscometry during cardiopulmonary bypass}

Atsushi Nakamura

Abstract : During cardiac surgery with cardiopulmonary bypass (CPB), blood viscosity changes as blood temperature and hematocrit values change. Because blood viscosity has a high influence on hemodynamics in surgical patients, it can be a useful parameter during CPB. To measure blood viscosity, a rotational viscometer is commonly used. When using rotational viscometer, blood sampling is required and measuring blood viscosity during $\mathrm{CPB}$ in real time is difficult. Thus, blood viscosity is not routinely monitored. In this study, we proposed a system for measuring blood viscosity during $\mathrm{CPB}$ in real time and evaluated its performance.

We constructed the system by utilizing an extracorporeal ultrafiltration circuit, in which a hemoconcentrator was incorporated. We applied the Hagen-Poiseuille equation to a fluid flowing through the circuit and programmed it to calculate the viscosity of the fluid using the flow rate and the pressure difference between the two sides of the hemoconcentrator.

We measured the viscosities of Newtonian glycerin solution, non-Newtonian xanthan gum solution, and bovine blood using this system and a commercially available rotational viscometer. In both measurement systems, we found that the viscosity was approximately constant in the glycerin solution, whereas it decreased with increasing shear rate in the xanthan gum solution and bovine blood. Error rates in both systems were $\leqq \pm 10 \%$. The flow in the hemoconcentrator is laminar and obeys the Hagen-Poiseuille law at a flow rate of $100-500 \mathrm{~mL} / \mathrm{min}$; therefore, we could efficiently calculate the viscosity using flow rate and pressure difference.

The change in blood viscosity during $\mathrm{CPB}$ has an influence on systemic vascular resistance and $\mathrm{CPB}$ circuit internal pressure. This method will enable us to not only measure blood viscosity during CPB in real time but also accurately assess systemic perfusion, by considering peripheral circulation in patients and blood viscosity in a CPB circuit.

Key words : blood viscosity, ultrafiltration circuit, oxygenator, pressure loss

○杏林大学 保健学部 臨床工学科 中村淳史 (Atsushi Nakamura) ₹ 192-8508 東京都八王子市宮下町 476

Department of Clinical Engineering, Faculty of Health Sciences, Kyorin University

476, Miyashita-machi, Hachioji, Tokyo, 192-8508, Japan

[原稿受領日 : 2013 年 11 月 28 日 採択日 : 2014 年 3 月 10 日] 


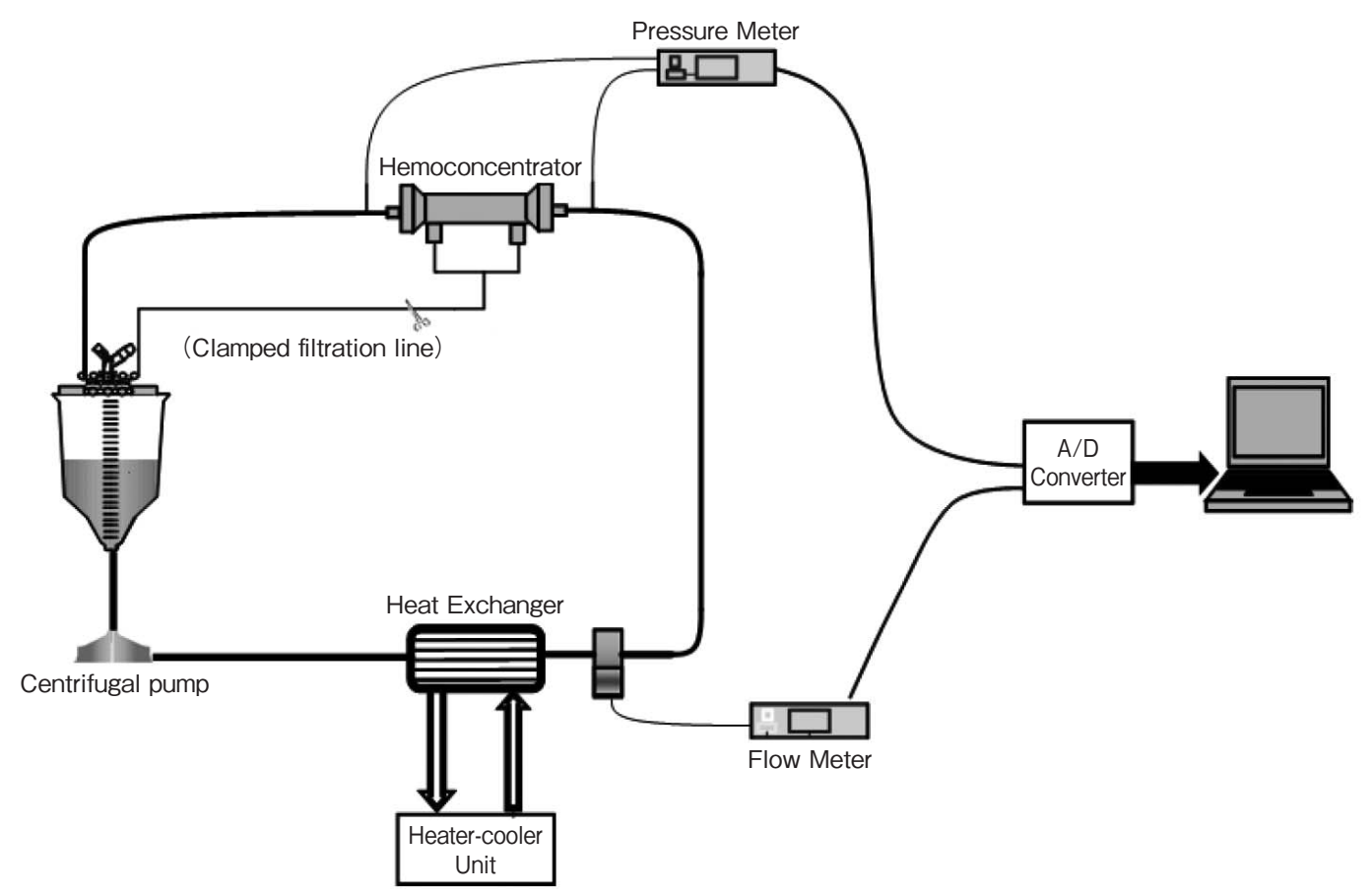

Fig. 1 Test ultrafiltration (UF) viscometry circuit

\section{I ． 緒言}

血液粘度は種々の疾患の病態を知るうえでの重要な 指標の一つである。血液粘度は、血球の大きさ、形状、 変形能、赤血球集合、ヘマトクリット值 (hematocrit: Hct)、血漿の性状、血液温度などの様々な条件によっ て変動し 1)、特に Hct と血液温度に大きく影響される。 人工心肺 (cardiopulmonary bypass：CPB) を使用し た開心術では、一般的に Hct は 15〜45\%、血液温度 は $20 \sim 37^{\circ} \mathrm{C}$ の範囲で変化し、それに伴い血液粘度も $\mathrm{CPB}$ 開始時から終了時まで変動する。この時の血液粘 度の変動は末梢循環、動脈圧に影響することが報告さ れている ${ }^{2-4)}$ 。その一方で、実際に CPB を操作する際 には、送血流量、Hct、血液温度などを意識しながら 送血回路内圧のモニタリングを行ったり、人工肺の血 栓形成による人工肺前後の圧較差の上昇に注意しなが ら人工肺の目詰まりの有無を判断したりと、血液粘度 の影響を受ける複数の要因に対して操作者が感覚的に 評価しているという現状がある。CPB 中における人工 肺前後の圧較差抢よび患者の循環動態を正確に把握す るためには、血液粘度の変化を連続的にモニ夕するこ とが必要であると考えられる。

血液粘度の測定には回転粘度計を使用するのが一般 的であるが、回転粘度計を使用する場合には血液の开 ンプリングを行わなければならない。そのため、簡便 性からリアルタイム性が要求される CPB 中の血液粘度 測定は事実上困難であり、血液粘度は CPB 中のルー チンのモニタリング項目とはなっていない。

過去の研究をさかのぼると、辻らが $\mathrm{CPB}$ 中の連続的
血液粘度測定法に関して人工肺を利用した測定法を開 発している ${ }^{5-7)}$ 。辻らは、中空糸（ホローファイバ）を 2 万本束ねた内部灌流型人工肺を使用し、その中空系 内部に血液を灌流させることにより、人工肺を流れる 血流量と人工肺前後で生じる圧力損失を測定し、HagenPoiseuilleの式を用いて血液粘度を算出した。しかし現 在では、人工肺の圧力損失軽減およびガス交換能向上 のため、血液が中空糸膜の外部を流れる外部灌流型の 人工肺が主流となっており、内部灌流型人工肺は国内 外問わず製造されていない。このため、リアルタイム に血液粘度を測定するのは困難な状況となっている。

本研究では、現在の CPB において使用されている限 外滤過（extracorporeal ultrafiltration：UF）回路を利 用してリアルタイムに血液粘度を測定できるシステム を作成し、模擬血液と牛血を用いて、その性能を評価 した。更に、生体を模擬した循環回路を使用して CPB 開始時の血液粘度の変化についてのシミュレーション を行い、作成したシステムより連続的に灌流液の粘度 を測定し、その実用性を評価した。

\section{II. 研 究方法}

\section{1. 測定方法および測定システム}

遠心血液ポンプ (HPM-05：泉工医科工業)、開放型 静脈賗血槽（TERUMO：RX-05)、および任意の血液 濃縮器を用いて作成した模擬循環回路に、圧力センサ （AP-48：キーエンス）と超音波流量計（HT-320：トラ ンソニック）を接続して、Fig. 1に示した測定システム を構築した。血液濃縮器の前後の圧較差を圧力センサ 


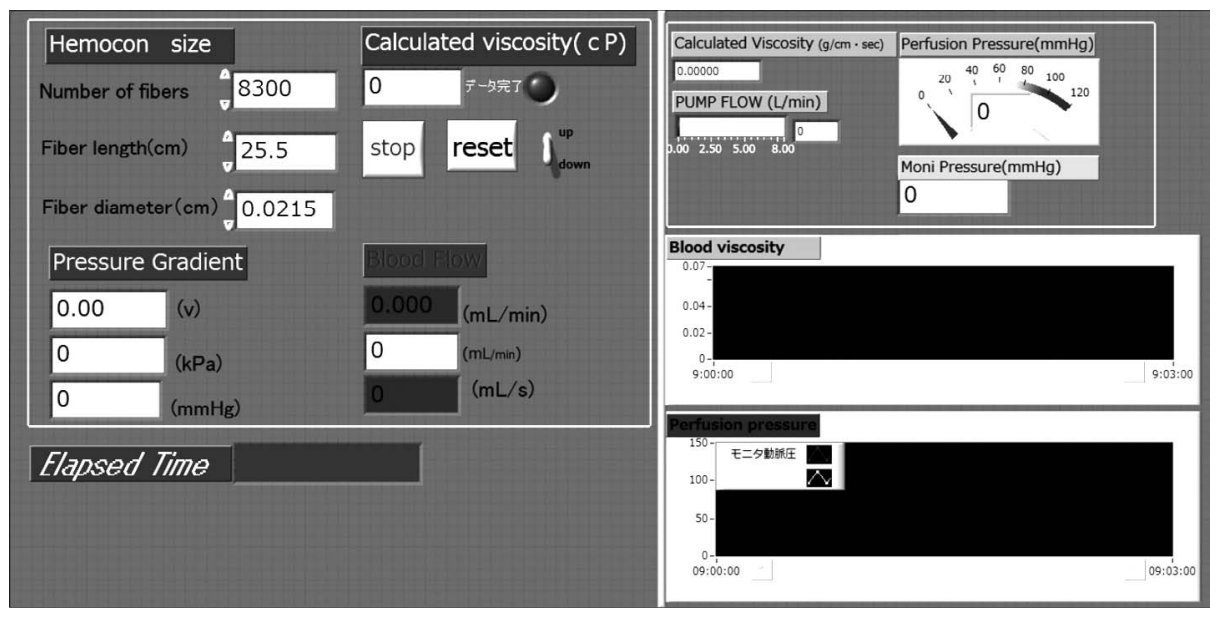

Fig. 2 Measurement parameters on the screen

で測定し、流量を超音波流量計で測定した。測定した 圧較差と流量の值をもとに、以下の Hagen-Poiseuille の式（1）を用いて血液濃縮器の仕様（中空子の本数、 長さ、内径）に対応して粘度を算出するプログラムを 作成した (Fig. 2)。プログラムの作成にはプログラミン グ言語 LabVIEW（ナショナルインスッルメンッ）を 用いた。

$$
\begin{aligned}
& \Delta P=\frac{128 \mu L Q}{\pi R^{4} N} \\
& P \text { : 圧力 }\left(\mathrm{dyn} \cdot \mathrm{cm}^{-2}\right) \quad \mu \text { : 粘度 }\left(\mathrm{g} \cdot \mathrm{cm}^{-1} \cdot \mathrm{s}^{-1}\right) \\
& L: \text { 中空糸長さ }(\mathrm{cm}) \quad Q: \text { 流量 }(\mathrm{mL} / \mathrm{s}) \\
& R \text { : 中空糸内径 }(\mathrm{cm}) \quad N \text { : 中空糸本数 (本) }
\end{aligned}
$$

血液濃縮器は BC 140 plus（MAQUET）を使用し、 各パラメータの值を中空糸長さ (ポッテイング部を含む): $25.5 \mathrm{~cm}$ 、中空糸内径 : $0.0215 \mathrm{~cm}$ 、中空系本数 : 8,300 本 に設定した。

\section{2. 模擬血液の粘度測定}

模擬血液とした $40 \%$ グリセリン水溶液とキサンタン ガム水溶液を溶液温度 $20 、 25 、 30 、 38^{\circ} \mathrm{C} て ゙ 、$ 流量をそ れぞれ 100、200、300、400、500 mL/min で灌流させた。 溶液温度は血液濃縮器入口、出口、除水ラインの 3 箇 所で計測した。除水ラインを開放した状態で溶液を灌 流させ、3 箇所の温度が安定した後、除水ラインを閉 じて粘度の測定を行った。測定は各 5 回行い、平均值 を使用した。また、同様の方法を用いて、牛血（Hct $20 \% 、 30^{\circ} \mathrm{C} ）$ の粘度を測定した。

測定デー夕取得後、測定回路より灌流液をサンプリ ングし、回転粘度計（DV-II + Pro：ブルックフィール ド）を用いて測定し、両者の測定値を比較した。流体 の粘度はニュートン流体と非ニュートン流体とでは性 質が異なり、非ニュートン流体の場合、ずり速度の影 響を受ける。そのため、回転粘度計のスピンドル回転 数は、各流量に打いて中空糸に対するずり速度（shear rate）を算出し、同じとなるように設定した。ずり速 度の算出には以下の式（2）を用いた ${ }^{8)}$

$$
\begin{aligned}
& \gamma_{w}=\frac{32 Q_{B}}{N \pi d^{3}} \\
& \gamma_{W}: \text { ずり速度 }\left(\mathrm{s}^{-1}\right) \quad Q_{B}: \text { 流量 }(\mathrm{mL} / \mathrm{s}) \\
& N: \text { 中空糸本数 }(\text { 本 }) \quad d: \text { 中空糸内径 }(\mathrm{cm})
\end{aligned}
$$

\section{CPB 開始時の連続的粘度測定}

生体の循環を模擬した装置に開放型 $\mathrm{CPB}$ 回路と $\mathrm{UF}$ 回路を接続し、 $\mathrm{CPB}$ 開始時に扔ける灌流液の粘度変化 を連続的に測定した（Fig. 3)。充填液として生体側には $40 \%$ グリセリン水溶液 $\left.5,000 \mathrm{~mL} （ 25^{\circ} \mathrm{C} 、 4.18 \mathrm{cP}\right)$ を、 $\mathrm{CPB}$ 回路には水道水 $1,500 \mathrm{~mL}\left(25^{\circ} \mathrm{C} 、 0.98 \mathrm{cP}\right)$ を充填させた。 血液濃縮器への灌流方法は A-V shunt 法で行い, pumpless とした。

\section{III. 研 究結 果}

\section{1. 模擬血液の粘度測定}

40\%グリセリン水溶液の各温度における作成したシ ステムにより測定した粘度は、流量にかかわらず一定 となり（Fig. 4）、回転粘度計で測定した結果（Fig. 5） と同様の結果が得られた（Table 1)。

キサンタンガム水溶液の粘度は、流量が増加するに従 い低下した (Fig. 6)。回転粘度計で測定した結果 (Fig. 7) においても、すべての温度でずり速度が上がるにつれ、 粘度が低下する特性となった（Table 2)。また、牛血 の測定結果は、流量が増加すると、わずかであるが粘 度が低下する傾向となった（Table 3)。回転粘度計で 測定した結果も同様の傾向を示した。

各模擬血液の測定結果を回転粘度計で測定した結果 と比較すると誤差は土10\%以内であった（Fig. 8)。

\section{CPB 開始時の連続的粘度測定}

$\mathrm{CPB}$ 開始時における灌流液の粘度変化を連続的に測 定した結果を Fig. 9 に示した。CPB 開始前には動脈圧 


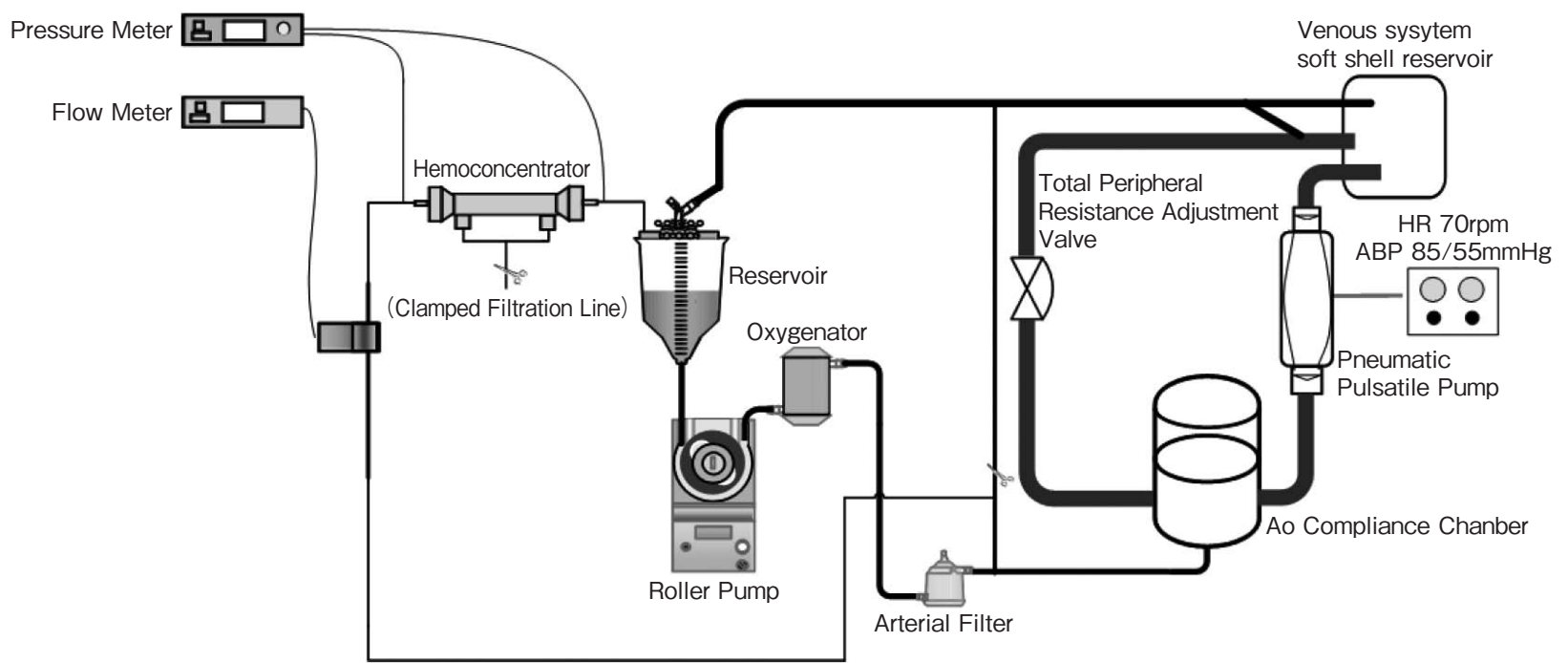

Fig. 3 Simulation circuit for measuring the change in viscosity at the beginning of CPB

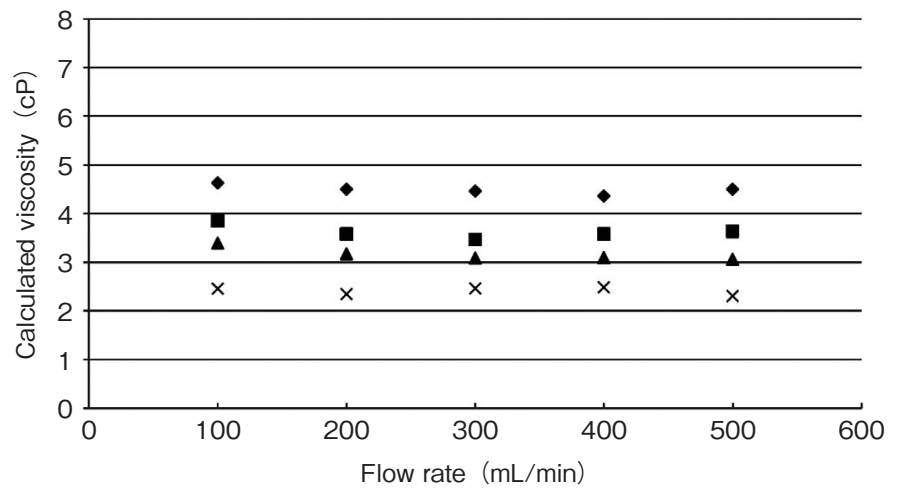

- $20^{\circ} \mathrm{C}$

- $25^{\circ} \mathrm{C}$

$\triangle 30^{\circ} \mathrm{C}$

$\times 38^{\circ} \mathrm{C}$

Fig. 4 Viscosity of Glycerin solution in UF viscometry

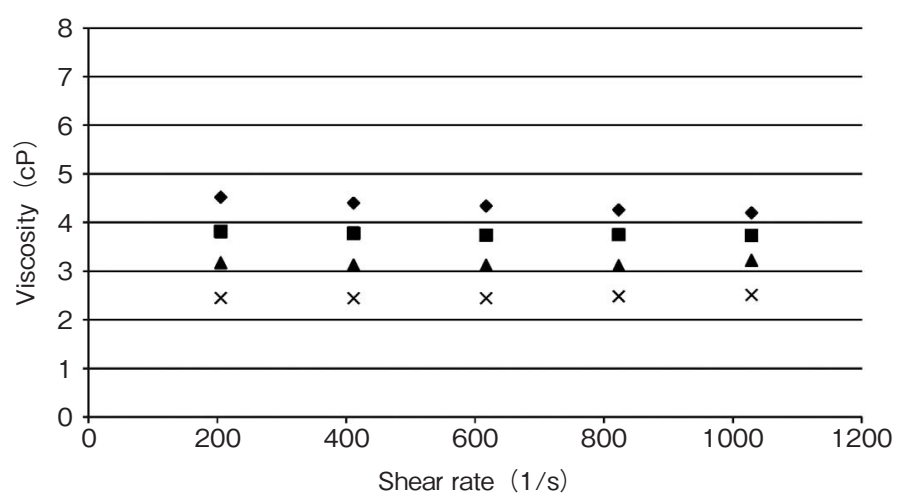

- $20^{\circ} \mathrm{C}$

- $25^{\circ} \mathrm{C}$

$\triangle 30^{\circ} \mathrm{C}$

$\times 38^{\circ} \mathrm{C}$

Fig. 5 Viscosity of Glycerin solution with a rotational viscometer

Table 1 Comparison of the viscosity of Glycerin solution in UF viscometry and that with a rotational viscometer

\begin{tabular}{ccccc}
\hline Flow $(\mathrm{mL} / \mathrm{min}) /$ Shear rate $(1 / \mathrm{s})$ & $20^{\circ} \mathrm{C}$ & $25^{\circ} \mathrm{C}$ & $30^{\circ} \mathrm{C}$ & $38^{\circ} \mathrm{C}$ \\
\hline $100 / 206$ & $4.63 / 4.52$ & $3.85 / 3.82$ & $3.39 / 3.17$ & $2.45 / 2.45$ \\
$200 / 412$ & $4.50 / 4.40$ & $3.58 / 3.78$ & $3.17 / 3.13$ & $2.34 / 2.44$ \\
$300 / 617$ & $4.46 / 4.34$ & $3.46 / 3.74$ & $3.08 / 3.12$ & $2.46 / 2.44$ \\
$400 / 823$ & $4.36 / 4.26$ & $3.58 / 3.75$ & $3.09 / 3.11$ & $2.48 / 2.48$ \\
$500 / 1,029$ & $4.50 / 4.20$ & $3.63 / 3.73$ & $3.06 / 3.22$ & $2.30 / 2.51$ \\
\hline mean $\pm \mathrm{SD}$ & $4.49 \pm 0.09 / 4.34 \pm 0.11$ & $3.62 \pm 0.13 / 3.76 \pm 0.03$ & $3.16 \pm 0.12 / 3.15 \pm 0.04$ & $2.41 \pm 0.07 / 2.46 \pm 0.03$ \\
\hline & & & UF viscometry/Rotational viscometer $(\mathrm{cP})$
\end{tabular}


に拍動が見られるが、CPBを開始させると徐々に脈圧 がなくなり、完全体外循環に移行していることがわか る。灌流液の粘度は CPB 開始後から上昇し、80 秒後
付近からほぼ一定となった。模擬血液として生体側を 循環していたグリセリン水溶液は希釈され、粘度が $4.18 \mathrm{cP}$ から $2.57 \mathrm{cP}$ まで約 $40 \%$ 低下した。
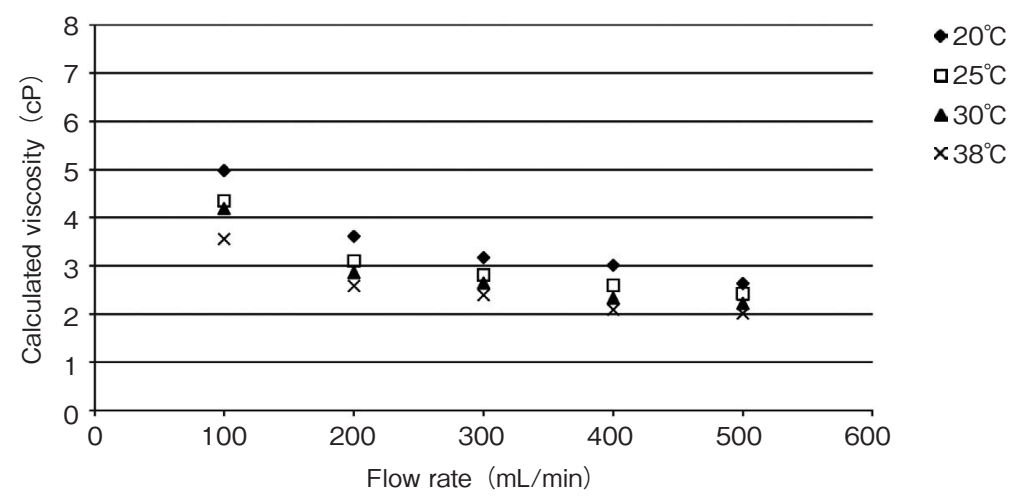

Fig. 6 Viscosity of Xanthan gum solution in UF viscometry

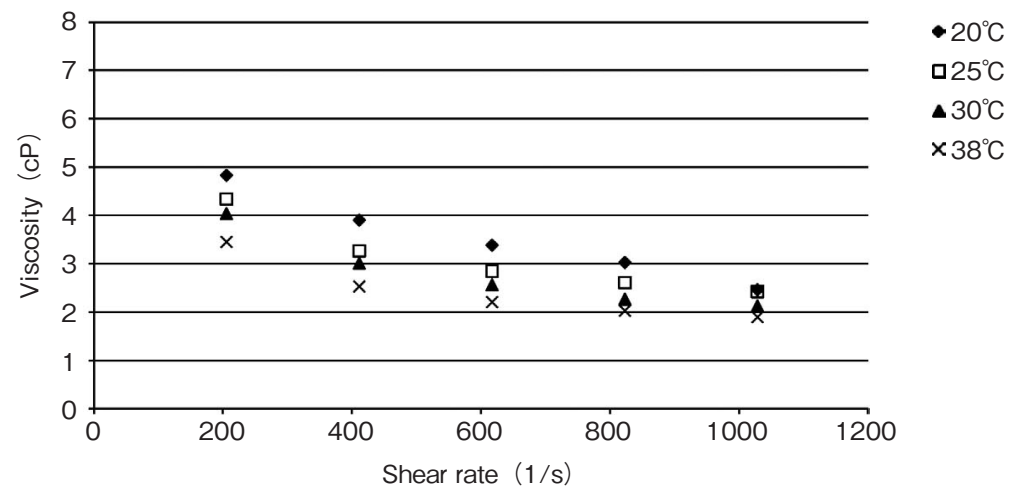

Fig. 7 Viscosity of Xanthan gum solution with a rotational viscometer

Table 2 Comparison of the viscosity of Xanthan gum solution in UF viscometry and that with a rotational viscometer

\begin{tabular}{ccccc}
\hline Flow $(\mathrm{mL} / \mathrm{min}) / \mathrm{shear}$ rate $(1 / \mathrm{s})$ & $20^{\circ} \mathrm{C}$ & $25^{\circ} \mathrm{C}$ & $30^{\circ} \mathrm{C}$ & $38^{\circ} \mathrm{C}$ \\
\hline $100 / 206$ & $4.98 \pm 0.13 / 4.83$ & $4.35 \pm 0.10 / 4.33$ & $4.19 \pm 0.15 / 4.03$ & $3.55 \pm 0.11 / 3.45$ \\
$200 / 412$ & $3.61 \pm 0.32 / 3.90$ & $3.10 \pm 0.03 / 3.26$ & $2.86 \pm 0.02 / 3.00$ & $2.58 \pm 0.03 / 2.52$ \\
$300 / 617$ & $3.17 \pm 0.46 / 3.38$ & $2.81 \pm 0.30 / 2.84$ & $2.64 \pm 0.04 / 2.56$ & $2.39 \pm 0.75 / 2.20$ \\
$400 / 823$ & $3.01 \pm 0.03 / 3.03$ & $2.59 \pm 0.01 / 2.61$ & $2.33 \pm 0.01 / 2.26$ & $2.09 \pm 0.01 / 2.02$ \\
$500 / 1,029$ & $2.63 \pm 0.01 / 2.46$ & $2.42 \pm 0.02 / 2.42$ & $2.22 \pm 0.01 / 2.12$ & $2.01 \pm 0.01 / 1.89$ \\
\hline
\end{tabular}

$\mathrm{UF}$ viscometry $($ mean $\pm \mathrm{SD}) /$ Rotational viscometer $(\mathrm{cP})$

Table 3 Comparison of the viscosity of bovine blood in UF viscometry and that with a rotational viscometer

\begin{tabular}{cc}
\hline Flow $(\mathrm{mL} / \mathrm{min}) /$ shear rate $(1 / \mathrm{s})$ & ECUM system viscometer(mean $\pm \mathrm{SD}) /$ Rotational viscometer \\
\hline $100 / 206$ & $2.61 \pm 0.04 / 2.51$ \\
$200 / 412$ & $2.50 \pm 0.04 / 2.45$ \\
$300 / 617$ & $2.55 \pm 0.04 / 2.43$ \\
$400 / 823$ & $2.47 \pm 0.07 / 2.43$ \\
$500 / 1,029$ & $2.39 \pm 0.13 / 2.34$ \\
\hline
\end{tabular}

(Hct $20 \%, 30^{\circ} \mathrm{C}$ bovine blood) 


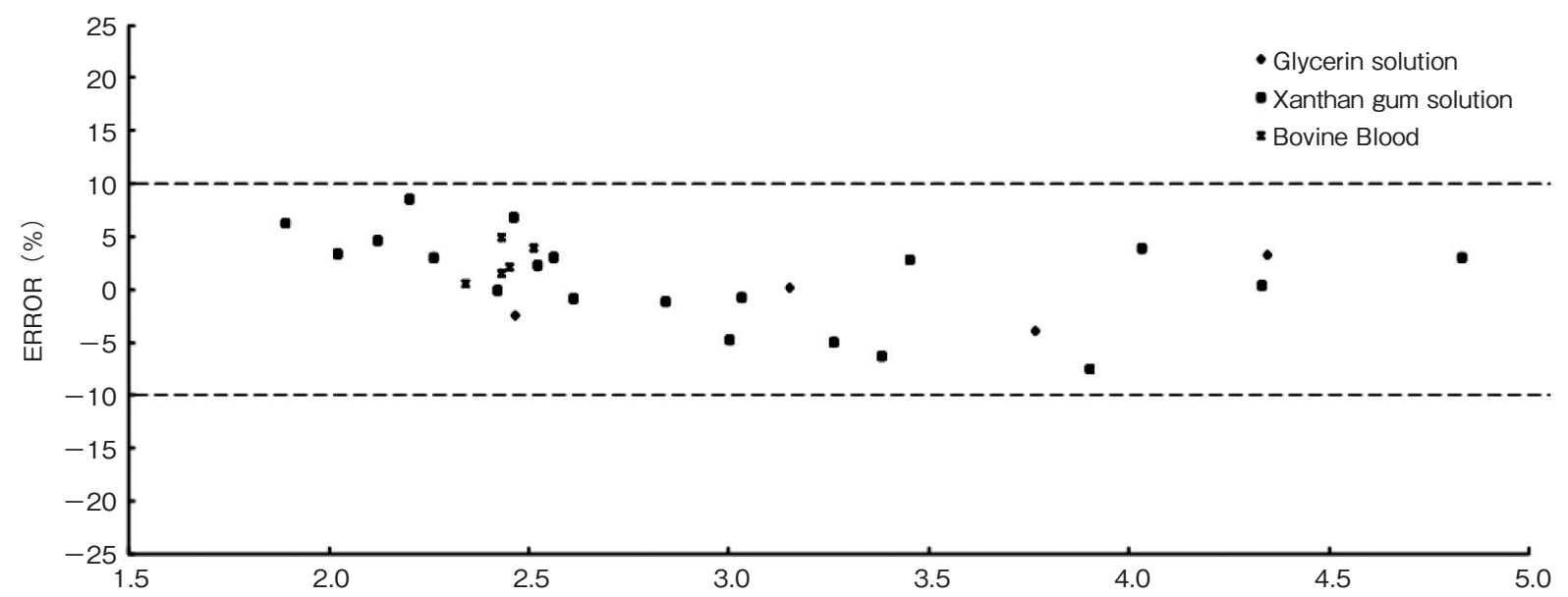

$(\mathrm{cP})$

Fig. 8 Error rate of UF viscometry

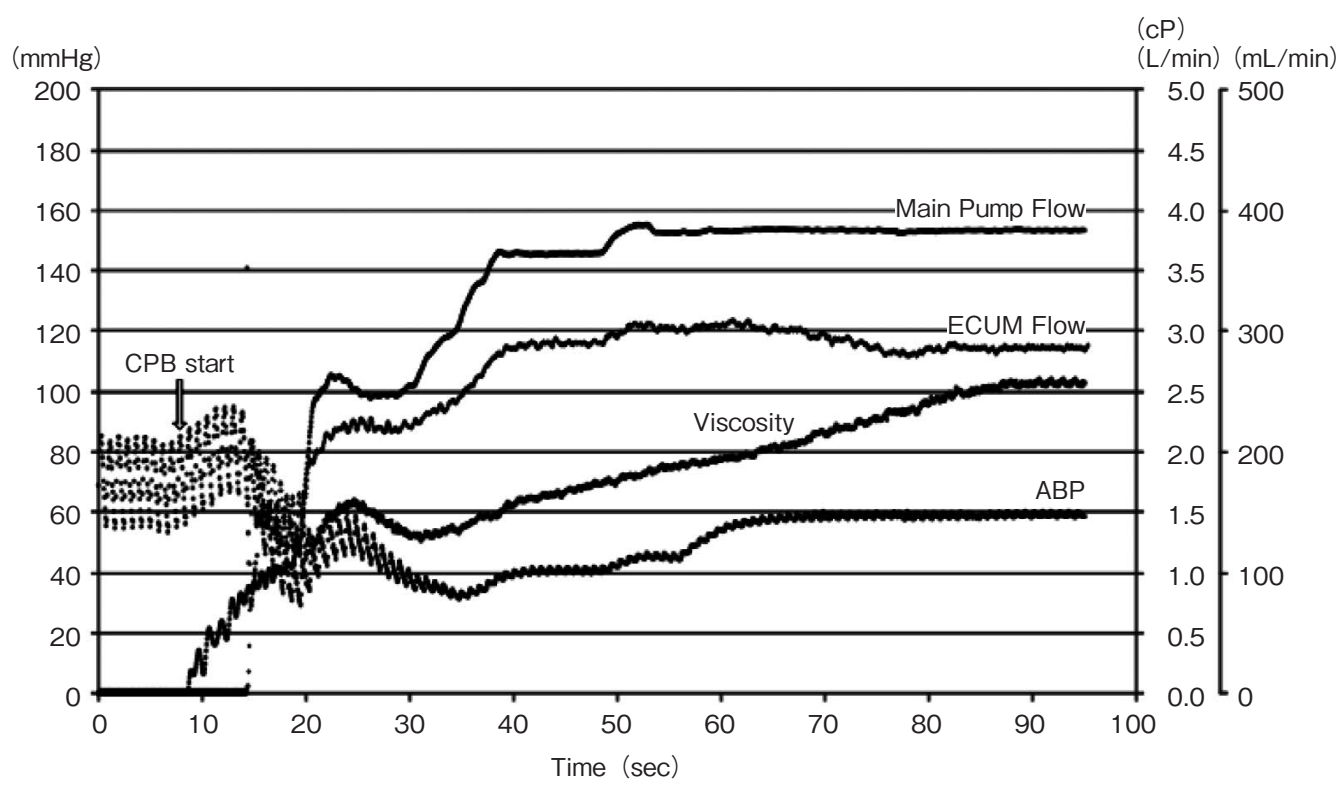

Fig. 9 Change in the viscosity of the perfusion fluid at the beginning of CPB

\section{IV. 考察}

\section{1. 測定結果について}

本研究で作成した測定システムは、血液濃縮器に発 生する圧較差と流量から流体の粘度を算出するもので ある。Fig. 10 に示したように、本システムを用いて粘 度を測定した結果（Y）と回転粘度計で測定した結果 （X）との間には $\mathrm{Y}=0.97 \mathrm{X}+0.12$ という関係が成立し、 両者の相関係数は $r=0.99$ となった。このことから、測 定システムは市販の回転粘度計と同様の精度を有して いることが判明した。

\section{2. 血液濃縮器内の流れについて}

流量 $100 \sim 500 \mathrm{~mL} / \mathrm{min}$ では、血液濃縮器内の流体 に対して Hagen-Poiseuilleの定理が成り立ち、圧較差 と流量が粘度に依存することがわかった。また本研究 における流量および粘度域内では、血液濃縮器内の流

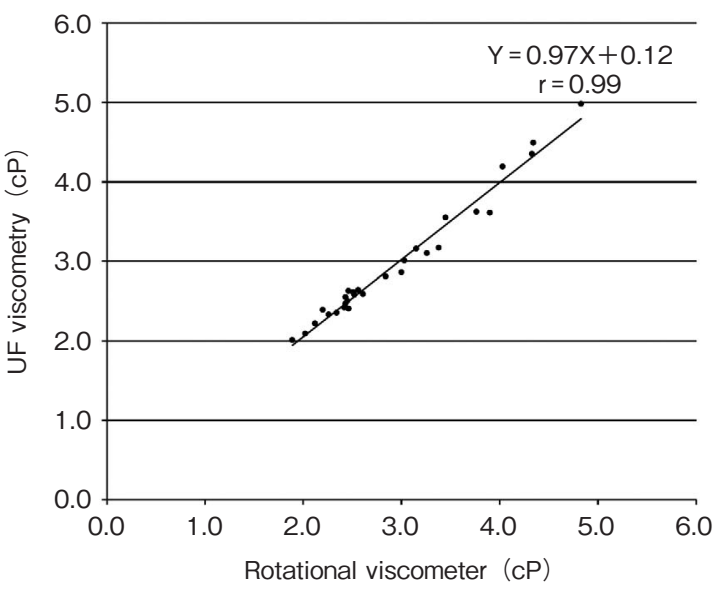

Fig. 10 Relationship between rotational viscometer $(\mathrm{X})$ and UF viscometry $(Y)$ 
れに対してレイノルズ数（Reynolds number：Re）を 算出すると $\mathrm{Re}=0.7 \sim 3.3$ となることから、血液濃縮 器内の流れは層流であると考えられた。

理論的に血液濃縮器前後に発生する圧較差は、中空 糸流入部に扔いて生じる圧力損失と中空糸内部で摩擦 によって生じる圧力損失の 2 つに起因すると考えられ る。中空糸の形態は直円筒型であり、流体力学におい て流体が円管を流れる場合の圧力損失 $\Delta \mathrm{P}$ は以下の式 （3）によって表すことができる。

$$
\begin{aligned}
& \Delta P=\xi_{1} \frac{\rho \bar{u}^{2}}{2}+\left(\lambda \frac{L i}{d}+1+\xi_{2}\right) \frac{\rho \bar{u}^{2}}{2}+\frac{32 \mu(L-L i)}{d^{2}} \bar{u} \\
& P \text { : 圧力 }(\mathrm{Pa}) \\
& \rho: \text { 密度 }\left(\mathrm{kg} / \mathrm{m}^{3}\right) \\
& \lambda: \text { 管摩擦係数 } \\
& d: \text { 中空糸内径 }(\mathrm{m}) \\
& L: \text { 中空糸長さ }(\mathrm{m})
\end{aligned}
$$

右辺の第 1 項は流入部損失を表す。流入部の形状によ り損失係数 $\xi_{1}$ が異なり、中空子ポッティング部の形状の 場合には $\xi_{1}=0.5$ となる。第 2 項は、流体が中空糸内に 入り、流れが発達するまでの助走距離損失を表す。層流 の場合には係数 $\xi_{2}=1.25 \sim 1.33$ となることが理論または 実験から示されている ${ }^{9}$ 。第 3 項は発達した流れにおけ る摩擦損失を示している。管摩擦係数 $\lambda$ と助走距離 $L i$ は、 層流域の場合、 $\lambda=64 / \mathrm{Re} 、 L i=0.065 \mathrm{Re} \cdot d$ から定まる。

本研究の流量、粘度域内に扔いては、第 1 項、第 2 項および第 3 項の助走距離 $L i$ は理論的にも無視できる ため、本手法を用いて流量と圧較差から血液粘度が測 定できたと考えられた。

\section{3. 各模擬血液の粘度特性}

$\mathrm{CPB}$ 回路の構成要素の流体特性を実験的に得るため には、ヒトや動物の血液を用いるのが理想的である。し かし、使用する血液の個体差、腐敗、感染症、倫理な どの問題により取り扱いが困難であることから、一般 的にはグリセリン水溶液を用いて実験が行われること が多い。血液浄化の分野では、血液側にグリセリン水 溶液を使用すると透析効果によりグリセリン濃度が低 下するため、グリセリンよりも分子量が大きいキサン タンガムを使用して実験が行われている。

流体の粘度は、水に代表されるようなニュートン流 体と血液のような非ニュートン流体とでは性質が異な る。ニュートン流体の場合、粘度は温度よって変化す るが、ずり速度の影響は受けない。Fig. 4 および Fig. 6 から、グリセリン水溶液とキサンタンガム水溶液とで は粘度特性が異なり、グリセリン水溶液はずり速度に 依存しないニュートン流体であるのに対し、キサンタ ンガム水溶液は、ずり速度が高くなるにつれて粘度が 低くなる非ニュートン流体であることがわかる。本研
究では、回転粘度計の測定結果と比較を行うために、 スピンドル回転数を各流量における中空糸に対するず り速度に合わせて設定し測定を行ったため、回転粘度 計の結果との誤差が少なくなり、回転粘度計と同様の 特性結果が得られたと考えられる。

本測定システムを用いて牛血の粘度を測定した結果 から、ずり速度の増加につれて粘度が低下する非ニュ ートン特性が得られた。血液の粘度特性はずり速度依 存性を示すことが知られているが、本研究のように血 液が細管内を流れる場合には Fahraeus 効果による影 響も考慮する必要がある。血液が細管内を流れる場合、 血液の流れは壁近傍に血漿層が形成され、赤血球は回 転しながら管軸方向へ移動する軸集中が起きる。この 軸集中現象の結果、赤血球が血漿に比べて細管内を速 く通過してしまい、細管内に留まっている赤血球の量 が少なく、ゆっくりと流れる血漿の量が増えることによ り Hct が低下する (Fahraeus 効果)。Hctが低下するこ とによって血液粘度は低くなる現象が起きる（FahraeusLindqvist 効果)。Fahraeus 効果は流路径 $300 \mu \mathrm{m}$ 以下 になると現れ、内径 $10 \sim 20 \mu \mathrm{m}$ で最大となるとされて いる ${ }^{10)}$ 。本研究で使用した血液濃縮器の中空子内径は $215 \mu \mathrm{m}$ であるため、上記の効果を考慮すれば本システ ムの測定值が回転粘度計と比べると低值となるはずで あるが、牛血（Hct $20 \% 、 30^{\circ} \mathrm{C}$ ）を測定した時の誤差 はわずかであった。これは内径 $215 \mu \mathrm{m}$ では FahraeusLindqvist 効果の発現が弱く、結果には影響を与えなか ったためだと考えられる。しかしその効果は、流路径 だけでなく赤血球量からも影響を受けるため、Hctが 高くなれば、算出された粘度值が回転粘度計と比較し た場合に低值を示すと考えられる。

\section{4. 生体内における血液粘度}

血液は、ずり速度が $50 \mathrm{~s}^{-1}$ 以上になると粘度の変化 が少なくなっていき、200 $\mathrm{s}^{-1}$ 以上になるとほぼ一定の 值となり、200s ${ }^{-1}$ 以上の流れではニュートン流体とみ なすことができる。生体内でのずり速度は血管部位によ って異なり、大動脈から細動脈の間では $400 \sim 1,200 \mathrm{~s}^{-1}$ であり ${ }^{11}$ 、流体摩擦抵抗が大きく圧較差が生じる。今 回使用した血液濃縮器内のずり速度は血液流量が 100 〜 500 mL/min で $206 \sim 1,030 \mathrm{~s}^{-1}$ であることから、そ の領域における測定が可能と考えられる。

\section{CPB 中の血液粘度測定（末梢循環の評価）}

$\mathrm{CPB}$ を用いた開心術で最も急激な血液粘度の変化が 見られるのは $\mathrm{CPB}$ 開始時の $\mathrm{CPB}$ 回路の充填液と患者 血液が混ざり合う時期であり、初期血圧低下（initial drop）を起こす一因となっている。原因としては体血 管抵抗（systemic vascular resistance：SVR）の低下に よるもので、血液希釈による血液粘度の低下、内因性 の catecholamine 血中濃度の低下、bradykinin の影響、 
拍動流から定常流への変換などが考えられている ${ }^{12) 。 ~}$ このように initial drop の原因は血液希䣋によるものだ けでなく、血管作動性物質による影響もあるが、晶質 液充填と血液充填でそれぞれ常温 $\mathrm{CPB}$ を行い、その時

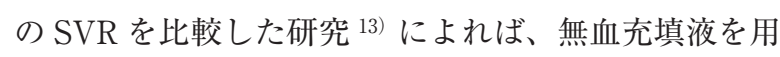
いた場合には急激な SVR の低下が見られるが、血液充 填では見られないという結果が報告されていることから、 $\mathrm{CPB}$ 開始時の SVR の低下は血液希釈による血液粘度の 急激な減少による要因が強いと考えられる。また Gordon らは一定の灌流量で CPB を施行している間、灌流圧は血 液粘度の変化に比例して低下することを示している ${ }^{14)}$

臨床に押いて患者の循環動態を把握するには心拍出 量 (cardiac output:CO) あるいはポンプ流量 (pump flow : PF)、平均動脈圧 (mean arterial pressure: MAP)、 中心静脈圧 (central venous pressure : CVP) から SVR $=(\mathrm{MAP}-\mathrm{CVP}) /(\mathrm{CO}$ or $\mathrm{PF})$ を用いて末梢循環の評 価を行っている。しかし、この方法を血液粘度の変化 が大きい CPB 症例に適用すると、SVR の変化が血液 粘度の変化によるものなのか、vasomotor activity に よるものなのか判別できない。このように $\mathrm{CPB}$ 中の循 環動態を評価するためには血液粘度の変化を考慮した SVR 評価が必要であり、本手法を用いることによりリ アルタイムに血液粘度の変化を考慮した適切な末梢循 環評価が可能であると考えられる。

\section{CPB 中の血液粘度測定（安全対策）}

$\mathrm{CPB}$ 施行中、送血カニューレの先あたり、偽腔送血、 回路の屈曲、動脈フィルタや人工肺の目詰まりなどが 原因となり、送血回路内圧が異常に高くなる現象が発 生することがある。そのため、安全に $\mathrm{CPB}$ を施行する ためには、送血側の回路内圧を測定し、常時モニタリ ングを行うことが久かせないものとなる。実際に、日 本体外循環技術医学会による安全装置設置基準では、 送血圧（送血ポンプと人工肺の間）の測定は必須とさ れている。更に、人工肺の目詰まりを検出するため、 送血圧とは別に送血フィルタの入口圧を常時モニタで きることを推奨している ${ }^{15)}$ 。しかし、回路内圧は送血 流量のみならず、血液粘度の影響を強く受けており、 送血側回路内圧を適切に評価することは難しい。また、 人工肺や動脈フィルタ内では血液の流れが乱流となる ことや、人工肺や動脈フィルタは種類によって圧一流 量特性が異なること、更には人工肺の圧力損失は流体 の粘度に大きく依存する ${ }^{16)}$ ことも、回路内圧の適正な 評価を困難にする要因となっている。

今回、UF 回路を用いて算出した粘度は、血液が細 管内を流れることを想定した場合の「見かけ」粘度で あるが、本システムで測定された粘度值をリアルタイ ムに測定し、その変化を定量的に認識することによっ て、人工肺、動脈フィル夕、回路、カニューレなどの
$\mathrm{CPB}$ 回路の各構成要素の状態評価が可能であると考え られる。特に人工肺や動脈フィルタなどの圧較差を評 価する際には、体外循環操作者に有用なモニタリング 指標であると考えられる。

\section{V. 結語}

CPB 中において UF 回路を利用してリアルタイムに 灌流液の粘度を測定することが可能である。 $\mathrm{CPB}$ 症例 において血液粘度の測定は重要であり、灌流液の粘度 変化を定量的に認識することによって、患者末梢循環 や CPB 回路の血液粘度を考慮した適切な灌流状態評価 が可能である。

\section{参考文献}

1）谷口興一：血管（円筒管）内を流れる流動を考える。循環 制御, 28 (3)；185-193，2007.

2）阿部伸夫：血液希釈と体外循環時の末梢循環に関する実験的研 究一特に血液粘度を中心として一. 慈恵医大誌, 96（3）; 560-579, 1981.

3）草川 實, 大井 勉, 新保秀人, ほか：体外循環中の末梢 循環. 循環制御, 4(2)；211-219，1983.

4）藤井壮一: 体外循環における血液粘度の変動に関する研究. 麻酔, 21 (12)；1199-1207, 1972.

5）辻 隆之, 田村俊世, 須磨幸蔵, ほか：ポリプロピレンホ ローファイバ人工肺を応用した体外循環時の血液粘度测定 法の開発. 人工蔵器, $12(2) ; 449-452,1983$.

6）辻 隆之, 鹿島良和, 戸川達男, ほか：ポリプロピレン・ ホローファイバ人工肺を用いた血液細管粘度連続計測方の 開発. 医用器材研報, $18: 67-74,1984$.

7）辻 隆之, 戸川達男, 岡本 誠, ほか：微細管を応用した 新しい粘度計測法の開発とヒト血漿粘度に関する研究. 日 本バイオレオロジー学会誌, 1 (2)；22-30, 1987.

8) 峰島三千男 : 血液浄化器. 第 1 版, 東京, 日本メディカル センター. 2002. p56-59.

9）金原 粲 (監): 流体力学. 第 1 版, 東京, 実教出版. 2009 . p145-183.

10) Maeda $\mathrm{N}$ : Erythrocyte rheology in microcirculation. Jpn J Physiol, 46 ; 1-14, 1996.

11) Kamiya A, Bukhari $R$, Togawa $T$ : Adaptive regulation of wall shear stress optimizing vascular tree function. Bull Math Biol, 46 (1) ; 127-137, 1984.

12）小林 彰, 下川新二, 平 明, ほか：体外循環中の体血管 抵抗に関与する要因の検討. 人工臓器, 27 (1)；76-80, 1998.

13) Robicsec F, Masters TN, Niesluchowski W, et al. : Vasomoter activity during cardiopulmonary bypass. Pathophysiology and techniques of cardiopulmonary bypass. Vol II , Baltimore, Williams\&Wilkins. 1983. p1-12.

14) Gordon RJ, Ravin M, Daicoff GR, et al. : Changes in arterial pressure, viscosity and resistance during cardiopulmonary bypass. J Thorac Cardiovasc Surg, 69 (4) ; 552-561, 1975.

15）日本体外循環技術医学会：人工心肺における安全装置設置 基準（第四版）

http://jasect.umin.ac.jp/safety/pdf/sefty.4th130908.pdf.

16）岡村直哉, 徳嶺朝子, 二宮信治, ほか：人工肺の流体力学特 性に関する基礎的検討. 体外循環技術, 37 (3)；347-350, 2010. 